\title{
Ethics, Adverse Selection, Target Method of Sale Strategies, and Akerlof's "Lemons" Problem
}

\author{
Carol L. (Anilowski) Cain ${ }^{1}$, Gary M. Fleischman², Antonio J. Macias ${ }^{3} \&$ Juan Manuel Sanchez ${ }^{4}$ \\ ${ }^{1}$ College of Arts, Sciences, Business and Education, Winston-Salem State University, Winston-Salem, NC, USA \\ ${ }^{2}$ Rawls College of Business, Texas Tech University, Lubbock, TX 79409, USA \\ ${ }^{3}$ Hankamer School of Business, Baylor University, Waco, TX, USA \\ ${ }^{4}$ College of Business, University of Texas at San Antonio, San Antonio, TX, USA \\ Correspondence: Gary M. Fleischman, Rawls College of Business, Texas Tech University, Box 42101, Lubbock, TX \\ 79409-2101, USA.
}

Received: April 3, 2021

Accepted: June 18, 2021

Online Published: June 21, 2021

doi:10.5430/afr.v10n3p1

URL: https://doi.org/10.5430/afr.v10n3p1

\begin{abstract}
This study examines the acquisition dynamics associated with the target management's choice to initiate the sale of the firm using the auction method. Specifically, we examine opportunistic merger and acquisition (M\&A) dynamics related to the target-initiated method-of-sale decision (auctions vs. one-on-one negotiations), as a noteworthy example of Akerlof's (1970) theory of the market for lemons. While we find a strong positive relationship between proxies of adverse selection risk and the likelihood of target initiation, robustness tests suggest target initiation itself is a unique indicator of information asymmetry in an acquisition environment. We also find that most target-initiated transactions follow an auction as the method of sale, which increases target information asymmetry advantages. While wealth accrued to both bidders and targets increases in non-target-initiated auctions, this benefit disappears when the target initiates the acquisition, causing both bidders and targets to suffer wealth losses. According to Akerlof's theory, these wealth losses represent the cost of perceived dishonesty due to enhanced adverse section risk, which provides noteworthy implications for both business and society.
\end{abstract}

Keywords: acquisitions, auction, negotiation, information-asymmetries, adverse selection

\section{Introduction}

\subsection{Purpose and Introduction to the Issue}

The purpose of this study is to initially examine the acquisition dynamics associated with the target management's choice to initiate the sale of the firm as a salient example of Akerlof's (1970) theory of the market for lemons. We investigate the target's method-of-sale strategic decision (auctions vs. one-on-one negotiations), and assess both bidder and target resultant shareholder wealth effects. We are particularly interested in assessing heightened adverse selection risk in target-initiated auction sales that likely exacerbate Akerlof's "lemons" problem related to merger and acquisition (hereafter M\&A) buyers (bidder-acquirers) versus sellers (targets), where "lemons" refer to low quality target firms. Akerlof's (1970) "lemons" problem occurs because of perceived seller dishonesty that is a function of information asymmetry adverse selection that potentially permits sellers (targets) to overstate the value of their firm to buyers (bidder-acquirers), where bidders have difficulty identifying good versus bad (lemon) target deals. The problem is important in the M\&A context because the theory predicts that both bidder-acquirers and target-sellers will suffer wealth losses that are a function of contracting distrust (Akerlof, 1970). Perhaps equally distressing is that the "lemons" problem discourages the finalization of other potentially mutually beneficial transactions (Akerlof, 1970), which shrinks collective economic wealth. Collectively, these M\&A ethical dilemmas create noteworthy deleterious outcomes for accounting and finance, in particular, and for society, in general. After empirically exploring the deleterious impact that target-initiated auction sales have on both acquirer and target wealth, we subsequently explore plausible remedies to mitigate this M\&A problem.

Financial economists generally investigate the behavior of transactional agents by observing purely economic and financial factors, so our inquiry that includes theory-driven non-economic transactional factors such as integrity and ethics is rare (see, e.g., Arce, 2004). Relatedly, Erhard and Jensen (2014) argue that assessing integrity in finance 
research is essential. Specifically, they $(2014$, pp. 2) contend "integrity is a factor of production as important as labor, capital, and technology." Arce (2004, pp. 264) notes further that "[n]o less than five Nobel laureates and the father of modern economics recognize the importance of ethical behavior for the functioning of the marketplace." We posit that this literature (e.g., Arce, 2004; Erhard \& Jensen, 2014) justifies our assessment of integrity-related issues such as opportunism, ethics, adverse selection risk, and Akerlof's "lemons" problem in the context of target M\&A method of sale strategies. Accordingly, we employ Akerlof's (1970) theory of the market for lemons as our study theoretical lens, which ties to accounting and finance ethics- and integrity-related issues directly (Kaplan, Roush, \& Thorne, 2007) given that adverse selection risk is associated with buyer and seller collective wealth losses due to theoretical and perceived seller dishonesty. Specifically, we investigate the potential unethical actions of selling company managers in trying to arrange auction sales that benefit their own firm due to information asymmetry advantages, while potentially damaging the acquiring firm. We also acknowledge that the actions of the selling company managers may not align with the M\&A outcome that the selling firm's shareholders would necessarily desire, but shareholders are likely unaware of this opportunistic behavior due to how subtle the auction method of sale is to external stakeholders. In sum, this context highlights important societal and finance ethical conflicts that may inflict significant pecuniary losses for unwary bidders (buyers).

\subsection{Importance of the Issue}

The ethics literature underscores that ethical dilemmas are especially salient in the M\&A context, yet are rarely studied, which is a gap in the literature that we address presently. For example, Lin and Wei (2006) argue that ethical considerations are likely magnified further during merger and acquisition (M\&A) activity due to increasing pressures to grow and to deliver higher levels of earnings. The authors (pp. 96) cite M\&A failure rates that may exceed 50 percent, with unethical behavior playing a critical role in such failures. Lin and Wei (2006) also argue that little is known about ethical considerations in relation to M\&A activity in general. This noteworthy gap in the literature is a problem as the impact of unethical behavior in the M\&A context can be serious, given both the sheer number of M\&A deals that take place each year in the USA (over 10,000 in 2005 and 12,000 in 2016) and their economic significance, with some deals exceeding a billion dollars (WilmerHale, 2005; Statista, 2017). Figure 1 depicts the proportion of M\&A transactions that are completed and withdrawn from 1989 to 2017. The range of withdrawn (failed) deals varies from $8.7 \%$ to $35.1 \%$ during this period.

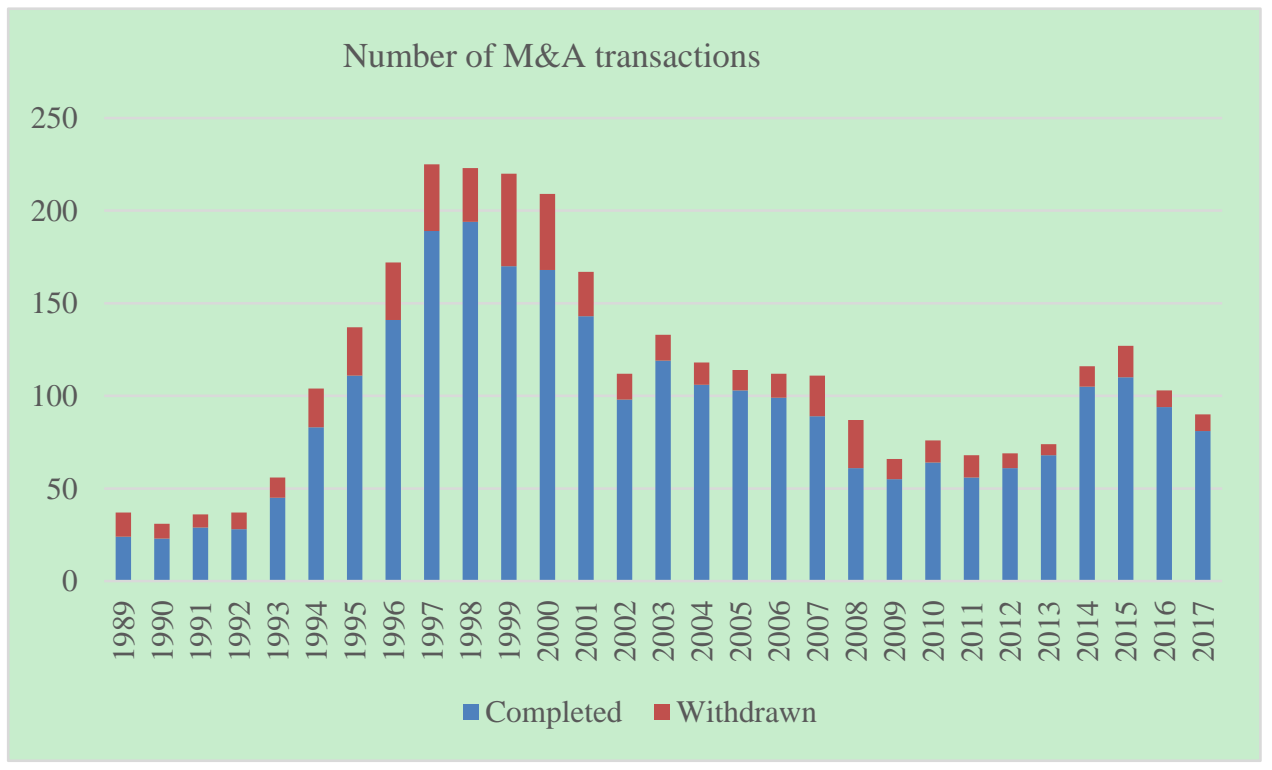

Figure 1. Proportion of M\&A transactions that are completed and withdrawn (failed) 1989-2017

This data underscores the magnitude of the potential consequences of unethical behavior in the M\&A context relating to pecuniary costs to victim bidders (buyers). Anecdotal evidence suggests that M\&A activity has increased considerably after the 2017 Tax Cuts and Jobs Act, further underscoring the study's importance.

Because of the importance of adverse selection opportunistic problems in general, and related M\&A activity in particular, we are motivated to investigate adverse selection dilemmas that relate to M\&A acquisition dynamics. Specifically, we investigate target-initiated sales where the target management (seller) chooses the auction, rather than one-on-one negotiations with the acquisition-bidder (buyer), as the method of sale vehicle. The auction method 
of sale limits the bidder-acquirer due diligence time period (bidders' window) and also allows target sellers greater latitude to exclude information deemed sensitive due to security or competition concerns (Hansen, 2001; Kummer \& Sliskovic, 2007; Boone \& Mulherin, 2009). We posit that target sellers therefore strategically select the auction method of sale when they wish to misrepresent information in some fashion. We predict that the target may have something to hide from the bidder acquirer, meaning that the target wishes to withhold key valuation information in order to gain a higher bid price, and / or present information in a more favorable manner. Accordingly, our first research question is: Do target sellers that initiate the auction method of sale present greater adverse selection risk to bidders?

\subsection{Akerlof's Theory}

Akerlof (1970) posits a theory of the market for lemons that is descriptive of the present study's adverse selection ethical dilemma faced by acquirer bidders when a target initiates an auction rather than a one-on-one negotiation. According to Akerlof's theory, the target (seller) may be able to opportunistically manipulate the bidder (buyer) with lower quality products in the short term, but in the long term the seller's unethical activity will cause its reputation to deteriorate such that its product (firm) becomes worthless or highly devalued, which reflects a societal and reputational cost of dishonesty. A critical assumption of Akerlof's theory is that the buyer has difficulty distinguishing between good and bad products because of seller insider information advantages. We therefore expect target corporations that strategically initiate an auction method of sale with an acquirer-bidder in order to leverage "hidden" information will be penalized by the market for their perceived (theoretical) dishonesty (Akerlof, 1970). Consequently, our second research question is: Do target sellers that initiate the auction method of sale to acquirer-bidders suffer a wealth discount due to greater adverse selection risk? Ultimately, our second research question is a test of Akerlof's (1970) theory in the context of M\&A dynamics. We wish to learn how investors price perceived theoretical unethical adverse selection target behavior. Accordingly, the purpose of the study is first to determine if target-initiated sales are associated with greater adverse selection risk, and then to determine the business wealth dishonesty penalty associated with Akerlof's (1970) theory.

\subsection{Summary of Findings and Contribution}

We find significant positive relationships between the likelihood of target initiation and several proxies for adverse selection risk including, but not limited to, the standard deviation of accruals, which suggests earnings management (Dechow \& Dichev, 2002), and heightened asymmetric uncertainty (Raman et al., 2013). Collectively, these results present direct evidence that target initiation conveys adverse selection risk. Our analysis also shows that target initiators are more likely to auction the firm, in an attempt to leverage the ability to hide information.

Regarding the impact of the method-of-sale decision on bidder and target shareholders' wealth, the largest total transaction surplus gains and bidder long-term (LT) returns occur in auctions when the target does not initiate. Overall, our results indicate that both bidders and targets benefit from an auction process when the adverse selection risk is relatively lower (non-target-initiated transactions), while both parties suffer wealth declines when the target initiates the auction method and adverse selection risk is relatively higher, consistent with Akerlof's (1970) theory. Our results are also robust to alternate variable definitions and endogeneity concerns.

Our study contributes to both the ethics and M\&A literatures in several ways by addressing both pecuniary business and non-pecuniary market reputational factors. We are unaware of any empirical accounting and finance ethics study that employs firm-specific data to assess bidder versus target adverse selection and wealth effects to comprehensively assess Akerlof's (1970) theory of the market for lemons. The study also contributes to the M\&A literature by extending the seminal Boone and Mulherin $(2007 a ; 2007 b ; 2008 ; 2009)$ papers by uncovering further heterogeneity in the pre-announcement process by identifying the party that initiates the transaction and documenting its strong impact on acquisition dynamics. We show that non-target-initiated acquisitions drive the benefit from auctions, and that the target-initiation discount assumed by Boone and Mulherin (2009) and Aktas et al. (2010) is significant, both economically and statistically, due to adverse selection risk which is consistent with Akerlof's theory. Our findings also further elucidate why target-initiated auction deals likely have higher adverse selection risk, which supports the contention of Masulis and Simsir (2018) that the target's managers' private information is a key element of the information asymmetry between targets and bidders. We contend target-initiated deals enhance information asymmetry that in turn spurs further bidder distrust of the target, which the theory suggests is the perceived societal reputational cost related to seller dishonesty that proves costly to both target and bidder, a suboptimal conclusion. 


\section{Theory, Literature Review, and Hypotheses}

\subsection{Background Information about Auctions and Connection with Akerlof's Theory}

One of the main assumptions in an auction model with private information is that each bidder knows (or has a fair estimation of) the value of the target. If there is sizeable information asymmetry between the bidder and the target, this assumption is not realistic. As adverse selection risk increases, the probability that the bidder with the largest value creation potential is able to fairly estimate the target's value declines, a setting captured well by Akerlof's (1970) "lemons" problem.

Adverse selection exists ex ante to execution of the contract when agents possess hidden knowledge (Arrow, 1985) that is unavailable to the principal (Laffont \& Martimort, 2009). Kulkarni (2000) posits that adverse selection is concerned with agent unethical opportunistic behavior, given that Williamson (1985) defines opportunism to include a combination of self-interest and guile. Adverse selection may involve an agent purposely withholding critical information from the principal. Specifically, targets have strong incentives to provide optimistic information about the value of their firm (French \& McCormick, 1984; Christie \& Zimmerman, 1994), and the potential to present the firm's value in a better light by using income increasing accounting (earnings management) choices (Erickson \& Wang, 1999). Therefore, adverse selection risk is a key concern for interested bidders who may not have the same time or access to perform extensive due diligence in a competitive auction environment as they would in a one-on-one negotiation with a target of interest.

Bidders, on the other hand, are often the initiators of the transaction discussion with the target. We predict that adverse selection risk in bidder-initiated transactions is less of a concern to the bidder and contend that the risk of overpayment is lower. While bidders in general may find it difficult to determine if they are overpaying, those engaging in an auction will be at an information disadvantage given that bidder's access to information in an auction transaction generally is less complete compared to accessibility afforded in negotiations where they are the sole contender. In negotiations, the bidder is often granted on-site access to the target's management, employees, operations, and financial information until an agreement is reached. In contrast, an auction setting often results in the target's establishment of an off-site data-room where all bidders are granted access to selected financial information for a predetermined period of time (Boston Globe, 2004, and Kummer \& Sliskovic, 2007). In many cases, the access to target's information is restricted to "virtual data rooms" where bidders can only access data on-line. Bidders can possibly learn from each other about target privately held information, but subsequent evidence suggests that bidders face an information disadvantage in target-initiated auctions.

\subsection{Support for Hypothesis 1}

We contend that when the target initiates the sale and chooses to sell through an auction, the target can withhold value-relevant information to "prevent" the leakage of strategic information by invoking the competitive information effect (Hansen, 2001). Hansen (2001, pp. 32) states that "although the information given to potential buyers is extensive, it is not complete" since the target can claim some information is "too confidential to reveal," particularly if the bidding firm is a competitor, a supplier, or a customer (also see Boone \& Mulherin, 2009, pp. 35). Complementing Hansen's (2001) arguments, Kummer and Sliskovic (2007) state that targets can rationally justify limiting the information exchange on the grounds of security concerns (i.e., spying, confidentiality abuses, misuse of information).

Therefore, the target (seller) may be able to unethically mislead (Kurland, 1995) the bidder (buyer) to obtain a higher selling price. We predict that bidder adverse selection risk is magnified when the target strategically chooses an auction method of sale rather than a one-on-one negotiation because it minimizes the bidder's number of days to conduct target company due diligence while also permitting the target to withhold information potentially critical to the bidder under the guise that it is too confidential to reveal, which ties to our first research question at the outset. Katmon and Al Farooque (2017) suggest that the target may also participate in inappropriate earnings management to inflate value in the acquisition context. This accentuated information asymmetry permits the target to opportunistically misrepresent its value to the bidder. Collectively, the evidence suggests that target-initiated sales through an auction are associated with enhanced adverse selection risk, which explains our interest in connection with Akerlof's (1970) "lemons" problem. This leads to our first working hypothesis.

Hypothesis 1: Target sellers that initiate (do not initiate) the auction method of sale are associated with greater (lesser) adverse selection risk to bidders.

\subsection{Support for Hypothesis 2}

Past research suggests that the method-of-sale should impact expected wealth changes for the target (see e.g., 
Hirshleifer \& Png, 1989; Bulow \& Klemperer, 1996, 2002; Klemperer, 1999; Dasgupta \& Hansen, 2007; Ye, 2008; Masulis \& Simsir, 2018), with the bulk of the evidence suggesting that auctions yield, on average, higher wealth changes for targets (Dasgupta \& Hansen, 2007). Collectively, theoretical models of prior research (Povel \& Singh, 2006; Cantillon, 2008; Bulow \& Klemperer, 2009) suggest a separating equilibrium in which the target prefers either an auction or a negotiation based upon their privately informed estimation of transaction value. It is also plausible that targets initiate the sale knowing their firm is a "lemon" but aim to counteract a potential wealth discount by selling via an auction in which the bidders' access to information is more limited.

Akerlof's (1970) theory of the market for lemons describes the adverse selection ethical dilemma (see e.g., Jones 1995) faced by buyers (bidders) when attempting to purchase a seller's product (target firm), where the seller is perceived to withhold key valuation information that makes it difficult for the buyer to assess good versus bad (lemon) products. Specifically, Akerlof postulates the potential for seller dishonesty when two conditions are present: 1) both high quality and low quality (lemon) products are offered to buyers, and 2) product quality information asymmetry exists that favors the seller over the buyer. The lemons model postulates that in the short-term sellers will be incentivized to sell more and more lemons (less quality products), because of their information asymmetry advantage. However, in the long run sellers of the product will be labeled as dishonest, and their resultant poor ethical reputation will dissuade disillusioned buyers from purchasing the product at any price (Akerlof, 1970). This theoretical contention underscores the role of target firm ethical reputation in the long run. The model implicitly suggests that buyers learn in the long run, most likely through market forces and word of mouth. As stated above, we expect that target sellers that have the most to hide will initiate the auction method of sale with bidders, which heightens bidder adverse selection risk. Related to our second research question, we posit that target sellers that initiate the auction method of sale are penalized by society, resulting in a target-initiation market discount, consistent with Boone and Mulherin (2009) and Aktas et al.'s (2010) assumptions. We empirically test these assumptions and contentions in working hypothesis 2 .

Hypothesis 2: Target sellers that initiate (do not initiate) the auction method of sale are associated with a wealth discount (wealth surplus gains) due to greater (lesser) adverse selection risk to bidders.

\section{Sample Selection, Sales Process Description and Descriptive Statistics}

\subsection{Sample Selection and Description}

Using the Thompson Financial SDC M\&A database, we begin the construction of the sample by identifying all acquisition announcements of U.S. public targets by U.S. public bidders over the 1998-2005 period. We require that information exists in CRSP and Compustat, that the size of the target is at least $1 \%$ the size of the bidder, and that the market capitalization of the target is at least $\$ 2.5$ million. We require that the bidder seeks to gain control of the target (more than $50 \%$ of ownership sought in the transaction) because only these types of acquisitions must file the merger agreement with the SEC. Based on the pre-announcement takeover process described in SEC files described in more detail below, we identify three general classifications of acquisitions: auctions, negotiations, and unsolicited/hostile offers. We classify all multiple bidder acquisitions as auctions and single-bidder acquisitions as negotiations. We classify hostile or unsolicited transactions as non-target-initiated negotiations. After collecting the information from SEC filings, SDC, CRSP and Compustat, the final sample consists of 704 announced acquisitions.

While all data is publicly available, the background of the merger (pre-announcement takeover process) data collection exercise is far from trivial. We use the company and date information from the Thomson Financial database to search for the "background of the merger" disclosure detail information in the SEC EDGAR Company Filings and LivEdgar databases as Thomson Financial does not codify or collect the details regarding the pre-announcement takeover process. We must first locate the "background of the merger" section by searching through the firms' SEC filings (i.e., 8K, 10K, S4, DEF14A, SCTOT, SC 13D and any of their amendments). Once located, each "background of the merger" disclosure is read in its entirety while recording all pertinent information of interest for our study (e.g., dates for due diligence information access, number of bidders contacted at various stages, etc.). There is no way to data scrape the information from these disclosures as each disclosure is as unique as the transaction itself, with wide variation in the amount of detail provided from transaction to transaction. Table 1 provides Sample and Industry information for the study. 
Table 1. Sample Description, by target initiation

\begin{tabular}{|c|c|c|c|c|}
\hline & Total & $\begin{array}{c}\text { Target } \\
\text { Initiation }\end{array}$ & $\begin{array}{l}\text { Non- Target } \\
\text { Initiation }\end{array}$ & $\begin{array}{c}\text { Difference } \\
\text { (Target Initiation - } \\
\text { Non-Target Initiation) }\end{array}$ \\
\hline$[\mathrm{N}]$ & 704 & 317 & 387 & \\
\hline \multicolumn{5}{|l|}{ Method of Sale } \\
\hline Auction & 0.455 & 0.707 & 0.248 & 0.459 \\
\hline \multicolumn{5}{|l|}{ Target information asymmetry } \\
\hline Std. dev. of net income & 0.270 & 0.341 & 0.211 & 0.131 \\
\hline Discretionary accruals & 0.001 & 0.010 & -0.004 & 0.014 \\
\hline $\begin{array}{l}\text { Std. dev. of discretionary } \\
\text { accruals }\end{array}$ & 0.073 & 0.086 & 0.065 & 0.021 \\
\hline Asymmetric uncertainty & 0.099 & 0.105 & 0.096 & 0.009 \\
\hline Avg. institutional ownership & 0.401 & 0.335 & 0.456 & -0.121 \\
\hline Number of analysts & 2.307 & 1.707 & 2.798 & -1.092 \\
\hline \multicolumn{5}{|l|}{ Target financial distress } \\
\hline Altman's Z-score & 4.826 & 4.835 & 4.820 & 0.015 \\
\hline Interest coverage & 12.970 & 12.189 & 13.494 & -1.306 \\
\hline Liquidity ratio & 0.508 & 0.511 & 0.506 & 0.005 \\
\hline LT debt / EBITDA & 1.579 & 1.690 & 1.502 & 0.188 \\
\hline BHAR prior year & -0.024 & -0.018 & -0.029 & 0.011 \\
\hline \multicolumn{5}{|l|}{ Target firm characteristics } \\
\hline Mkt. value assets & 2.747 & 2.141 & 3.253 & -1.112 \\
\hline ROA (EBITDA/assets) & 0.057 & 0.036 & 0.075 & -0.039 \\
\hline Tobin’s Q & 1.805 & 1.693 & 1.900 & -0.207 \\
\hline R\&D-to-sales & 0.056 & 0.056 & 0.056 & 0.000 \\
\hline LT leverage & 0.174 & 0.164 & 0.183 & -0.019 \\
\hline Regulated industry & 0.374 & 0.476 & 0.289 & 0.187 \\
\hline Technology industry & 0.207 & 0.170 & 0.238 & -0.067 \\
\hline Strong anti-takeover state & 0.119 & 0.136 & 0.106 & 0.030 \\
\hline \multicolumn{5}{|l|}{ Bidder firm characteristics } \\
\hline Bidder mkt. value assets & 18.509 & 17.912 & 18.988 & -1.076 \\
\hline Bidder ROA (EBITDA/assets) & 0.112 & 0.094 & 0.126 & -0.033 \\
\hline Bidder Tobin's Q & 2.340 & 1.957 & 2.646 & -0.690 \\
\hline Bidder R\&D-to-sales & 0.049 & 0.047 & 0.051 & -0.004 \\
\hline \multicolumn{5}{|l|}{ Competition level } \\
\hline M\&A liquidity index & 0.154 & 0.189 & 0.124 & 0.065 \\
\hline Buyout activity & 0.391 & 0.410 & 0.374 & 0.036 \\
\hline Economic recession & 0.097 & 0.120 & 0.078 & 0.042 \\
\hline Internet bubble deflation & 0.273 & 0.293 & 0.256 & 0.038 \\
\hline \multicolumn{5}{|l|}{ Deal characteristics } \\
\hline Challenged deal & 0.057 & 0.016 & 0.090 & -0.075 \\
\hline Tender & 0.222 & 0.098 & 0.323 & -0.225 \\
\hline Diversified deal & 0.212 & 0.167 & 0.248 & -0.081 \\
\hline Only cash payment & 0.317 & 0.281 & 0.346 & -0.065 \\
\hline Hostile-Unsolicited & 0.126 & 0.000 & 0.230 & -0.230 \\
\hline
\end{tabular}

Table 1 describes firm, industry and deal characteristics for our final sample of 704 acquisition announcements of U.S. public targets by U.S. public bidders over the 1998-2005 period. We hand-collect from the SEC filings (i.e. 8k, 10k, S4, DEF14A, SCTOT, or SC13D) the specific merger agreement information for the negotiation terms. We confirm the general acquisition information from the SEC filings with the LivEdgar M\&A database. Target initiation is a 
categorical variable coded 1 if the target's management initiated the deal, and 0 otherwise. Variable definitions are in Appendix B. The asterisks, *** $\mathrm{p}<0.01, * * \mathrm{p}<0.05, * \mathrm{p}<0.1$, describe the significance of t-test (Satterthwaite, 1946) on the equality of means assuming that unpaired data have unequal variance (2-tailed tests unless a prediction is made). NS stands for Non-Significant.

\subsection{Announcement Date and Classification of Acquisitions}

The announcement date, defined as the first public announcement of the transaction, delineates the takeover pre-announcement period events from the post-announcement period.(Note 1) We define the announcement date (from Factiva and SEC filings), as the first trading date in which the bidder or the target publicizes the acquisition. For target initiated acquisitions, the pre-announcement takeover period usually begins with the target management making the decision to sell the firm and the intended method-of-sale to use: auction vs. negotiation. (Note 2) To classify an acquisition as target initiated, we read the "Background of the merger" section in the SEC files (DEF14A, S4, SCTOT, SC 13D, and their amendments), and detect when the target directly initiated the contact or hired legal or financial advisors to start the sale process with one or more bidders. For non-target-initiated acquisitions, the bidder initiates the initial contact. We then assess whether targets chose to auction the firm to multiple bidders or negotiate with a single bidder from the outset. In the case of an auction, the target selects the winning bidder from the offers received.

\subsection{Descriptive Statistics}

Untabulated descriptive statistics indicate that the annual number of observations ranges from a high of 160 in 1998 to a low of 39 in 2002, with auctions comprising $45 \%$ of the total sample. We find that $48 \%$ of all the M\&A transactions involve diversified transactions where the target and acquirer are in different industries based on the first 2 digits of their SIC industry classifications. We also find that target-initiated transactions represent approximately $45 \%$ of the transactions and that when the target initiates the sale, most opt for an auction: 71\% (224/317), particularly when both firms are in the same 2 digit SIC industry (73\%). In contrast, when the target does not initiate, only 25\% (96/387) of the acquisitions are auctions. We define our variables in Appendix A. Targets that initiate the sale of the firm are substantially more likely to follow an auction and have significantly higher levels of information asymmetry, when compared to firms where target management did not initiate the sale of the firm. Specifically, Std. dev. of net income, Discretionary accruals, the Std. dev. of discretionary accruals and Asymmetric uncertainty are significantly higher in target-initiated transactions. Similarly, Avg. Institutional ownership and the Number of analysts are lower for targets that initiated the transactions, relative to non-target-initiated transactions. Collectively, these results provide evidence that target firms with greater levels of adverse selection risk are more likely to initiate the sale of the firm. We also find that these untabulated results are largely driven by target-initiated transactions that pursue an auction as the method of sale, suggesting that targets initiating the sale of the firm pursue an auction as the method-of-sale in an attempt to constrain information sharing when adverse selection risk is high.

Untabulated descriptive statistics also indicate that there is a significant difference in the length (in days) of due diligence. (Note 3) On average, the number of days per bidder is approximately 16.4 days in target-initiated transactions, while it is approximately 24 days in non-target-initiated transactions. Similar patterns emerge when we consider the number of days of due diligence per bidder that signed a confidentiality agreement. These descriptive results are consistent with the notion that targets initiating the transaction look for many potential bidders while limiting the information sharing process, which suggests that higher levels of adverse selection risk are present in target- initiated transactions, particularly those that take place through an auction.

\section{Multivariate Specifications and Results}

In this section, we use logit regression to examine the impact of adverse selection risk on both the decision to initiate the sale of the firm and on the selection of the method of sale (H1). We then assess with logit regression how the decision to sell and method of sale decision affect the wealth gains in the acquisition using OLS specifications (H2), followed by SUR analysis to address the endogeneity concerns regarding both decisions. Appendix A defines our variables.

\subsection{The Impact of Adverse Selection Risk on the Decision to Initiate the Sale of the Firm}

The sale process and descriptive statistics are consistent with the conjecture that the target-initiation is associated with adverse selection risk. Next, we test these associations in a multivariate context using the following logit model for H1:

$$
\operatorname{Pr}(\text { Target Initiation }=1)=f(\text { Adverse Selection Risk, Controls })
$$


Target Initiation is a binary variable coded 1 if the target initiated the sale of the firm and 0 otherwise. Following prior research, we measure Adverse Selection Risk using the following proxies: Std. dev. of net income (Krishnaswami \& Subramaniam, 1999), Discretionary accruals (Kothari, Leone \& Wasley, 2005; Cornett, Marcus, \& Tehranian, 2008; Gong, Louis, \& Son, 2008), the Std. dev. of discretionary accruals (Dechow \& Dichev, 2002), and Asymmetric uncertainty (Dechow \& Dichev, 2002). We also consider the proportion of institutional ownership, Avg. Institutional ownership (Ashbaugh et al., 2006; Bhojraj \& Sengupta, 2003), and the number of financial analysts, Number of analysts (Lang \& Lundholm, 1996), since prior research finds that adverse selection risk and mispricing anomalies decrease in the presence of these two monitors. Positive (negative) and significant coefficients on Std. dev. of net income, Discretionary accruals, the Std. dev. of discretionary accruals, and Asymmetric uncertainty (Avg. institutional ownership and Number of analysts) would be consistent with the prediction that managers of target firms with higher levels of adverse selection risk are more likely to initiate the sale of the firm. Controls is a vector of control variables to capture the target's characteristics, including financial performance, the potential presence of rival bidders (latent competition), and industry-related fixed effects. We use only control variables known to the target at the time of the auction decision because that is their available information set. Adding variables known at the announcement date, yet not at the transaction (for example, relative target-bidder size or whether Target CEO stays in the firm after the acquisition), does not affect our inferences.

Table 2 presents the estimation results of equation (1). Columns (1-6) present the results after including each measure of adverse selection risk one at a time, in an effort to optimize the number of observations used to estimate each model. Column (7) presents the results after including all the measures of financial distress. Column (8) presents the most restrictive model after including all adverse selection proxies as well as all control variables. (Note 4) Consistent with our untabulated descriptive statistics, we find positive and significant coefficients on Std. dev. of net income, Discretionary accruals, the Std. dev. of discretionary accruals, and Asymmetric uncertainty, and negative and significant coefficients on Avg. institutional ownership and Number of analysts. None of the financial distress proxies are significant, even in untabulated tests after including each measure separately. Goodness of fit tests suggest that our model is well specified. Specifically, model (8) correctly classifies $69.1 \%$ of the target-initiated transactions and the Hosmer Lemeshow test and the receiver-operator characteristic (ROC) curve suggest we have a robust model (Hilbe, 2009). (Note 5) Collectively, these results are consistent with the notion that target initiation captures adverse selection risk, which supports H1.

Table 2. Determinants of Target Initiation- Logit Regression

Indep. Variable: $\operatorname{Pr}($ Trgt. Init. = 1)

$\beta /(\mathrm{p}$-val) $\quad$ - $\quad$ Model:

Std. dev. of net income

(1)

(2)

(3)

(4)

$0.177 * * *$

$(0.001)$

Discretionary accruals

$2.783 * *$

$(0.031)$

Std. dev. of discretionary accruals

Asymmetric uncertainty

Avg. institutional ownership

Number of analysts

Altman's Z-score

LT debt / EBITDA

\section{$3.900 * * *$}

(0.002)
(6)

(5)

(7)

(8)

$0.211^{* *}$

(0.032)

4.272**

(0.032)

$3.899 * * *$

(0.007)

\section{$3.947^{* *}$}

(0.020)

$-1.051^{* * *}$

(0.001)
$-0.198$

(0.362)

-0.041 *

(0.066)

(0.048) 
BHAR prior year

Log (Mkt. value assets)

ROA (EBITDA/assets)

$\log$ (Tobin’s Q)

R\&D-to-sales

LT leverage

Regulated industry

Technology industry

Strong anti-takeover state

M\&A liquidity index

Buyout activity

Economic recession

Internet bubble deflation

Intercept

Pseudo R2

$\mathrm{N}$
$-0.191 * * *-0.217 * * *-0.145 * *-0.171 * *-0.105$

$$
0.000
$$

0.146

$(0.001)$

(0.046)

$(0.028)$

(0.156)

0.273

$-0.442$

$-0.221$

(0.785) (0.625)

(0.614)

$(0.581)$

(0.604)

$0.399 *$

$0.391 * *$

0.128

0.179

$0.248 *$

(0.080)

(0.044)

(0.441)

$\begin{array}{lll}0.450 & 0.259 & 0.564\end{array}$

$0.280 \quad 0.473$

(0.518)

(0.248)

(0.196)

(0.419)

(0.154)

$-0.043$

0.067

0.060

(0.920) (0.414)

(0.921)

(0.873)

$(0.857)$

$0.967 * * * 0.532 *$

$0.694 * *$

$0.545^{* *}$

$0.622 * *$

0.000

(0.093)

(0.011)

(0.014)

(0.031)

$-0.425$

$-0.392$

$-0.174$

(0.301)

(0.325)

(0.589)

0.117

0.150

0.250

(0.728)

(0.642)

(0.185)

0.264

$-0.037$

$0.373 * * *$

$0.437 * * * \quad 0.562$

0.000

(0.389)

(0.709)

(0.939)

0.000

1.460

1.570

$2.109 * * *$

(0.130)

(0.008)

(0.002)

(0.009)

(0.204)

$-0.068$

0.089

0.149

0.054

(0.527)

(0.891)

$-0.093$

(0.827)

(0.846)

(0.709)

$-0.478$

$-0.469$

-0.782 *

(0.392)

(0.375)

(0.062)

Yes

(0.037)

0.060

Yes

623

0.043

Yes

0.044

Yes

0.037

424

328

363

Yes

0.065

610

The table presents Logit models on the probability of target initiation as a function of proxies of information asymmetry/adverse selection risk. Variable definitions are in Appendix A. Inferences are based on White (1980) standard errors corrected for within-industry and year dependence. The asterisks, *** $\mathrm{p}<0.01, * * \mathrm{p}<0.05, * \mathrm{p}<0.1$, describe the significance level of the coefficients (2-tailed tests unless a prediction is made).

\subsection{The Impact of Adverse Selection Risk on the Method of Sale}

The multivariate results in the previous section are consistent with the conjecture that the target-initiation captures adverse selection risk. Next, we test the likelihood that target initiated transactions lead to auctions as the method of sale. We test this prediction in a multivariate context using the following logit model to further test H1:

$$
\operatorname{Pr}(\text { Auction }=1)=f(\text { Target Inititated, Controls })
$$

where Auction is a binary variable coded 1 if the method-of-sale is an auction, and 0 otherwise. Our proxy for adverse selection risk is a binary variable (Target Initiation coded 1 if the target's management initiated the transaction, and 0 otherwise). A positive coefficient on Target Initiation would be consistent with the notion that targets' private information affects their preference to sell via an auction. In addition to controlling for all the factors specified in equation (1), Controls in model (2), also include each of the adverse selection risk proxies that we consider as explanatory variables in equation (1). 
To estimate the decision to sell through an auction and following equation (2), Table 3 presents four logit model specifications, with different sets of control variables for comparison purposes with prior research. For instance, Boone and Mulherin (2007a) includes two deal characteristics in the analysis of the method of sale, namely, the method of payment and tender indicator. For comparison purposes, we also estimate model (4) with these 2 variables, even though these variables are either simultaneously determined with the method of sale or determined afterwards. Appendix A defines these two additional controls. The results are consistent with our expectations: the coefficient of our adverse selection proxy (Target initiated) is positive and significant. (Note 6) The finding that target initiation has the largest economic impact and marginal effect relative to the rest of the control variables significantly contributes to the M\&A ethics literature. Specifically, if the target initiates the sale of the firm, depending on the model specification, the predicted probability of an auction is between $25.1 \%$ and $45.3 \%$ greater relative to non-target-initiated transactions, holding the other variables constant at their means. This predicted change is economically relevant given the baseline predicted probability of an auction is equal to $47.8 \%$. Showing a high concordance, the model correctly classifies $75.1 \%$ of the method of sale cases. We also find that the model has good fit based on two widely used tests, the Hosmer Lemeshow (2000) test and the receiver-operator characteristic (ROC) curve, which considers the specificity and sensitivity of the logit model (Hilbe, 2009). Collectively, Table 3 results support our prediction that target-initiated transactions generally lead to auctions as the method of sale. This further supports H1.

Table 3. Determinants of Method-of-sale - Logit Regression

Indep. Variable: $\operatorname{Pr}($ Auction. $=1$ )

$$
\beta /\left(\text { p-val) } \quad \beta /(\text { p-val }) \quad \beta /(\text { p-val }) \quad \beta /\left(\text { p-val) } \quad \begin{array}{l}
\text { Marginal effects // } \\
\text { [Predicted Change in Prob.] }
\end{array}\right.\right.
$$

\begin{tabular}{|c|c|c|c|c|c|c|c|}
\hline Model: & (1) & (2) & (3) & (4) & $\mathrm{CV}:-+\mathrm{s}$ & 2 an & DV:0->1 \\
\hline Target Initiation & $1.821 * * *$ & $1.757 * * *$ & $1.339 * * *$ & $1.098 * * *$ & 0.2508 & $1 /$ & {$[0.2528]$} \\
\hline & $(0.000)$ & $(0.000)$ & $(0.000)$ & $(0.000)$ & & & \\
\hline Log (Mkt. value assets) & $-0.107^{*}$ & $-0.174 *$ & $-0.268^{*}$ & $-0.280 *$ & -0.0640 & // & [-0.1207] \\
\hline & $(0.079)$ & $(0.078)$ & $(0.086)$ & $(0.098)$ & & & \\
\hline ROA (EBITDA/assets) & -0.740 & -0.389 & -1.728 & -1.551 & -0.3543 & // & [-0.0589] \\
\hline & $(0.142)$ & $(0.553)$ & $(0.353)$ & $(0.430)$ & & & \\
\hline $\log$ (Tobin's Q) & $-0.384 * *$ & $-0.357^{*}$ & -0.262 & -0.354 & -0.0808 & // & {$[-0.0454]$} \\
\hline & $(0.023)$ & $(0.085)$ & $(0.434)$ & $(0.302)$ & & & \\
\hline R\&D-to-sales & 0.658 & 0.282 & 0.521 & 0.631 & 0.1442 & // & {$[0.0361]$} \\
\hline & $(0.316)$ & $(0.685)$ & $(0.602)$ & $(0.516)$ & & & \\
\hline LT leverage & -0.452 & $-0.877 * *$ & -0.466 & -0.311 & -0.0711 & // & [-0.0149] \\
\hline & $(0.249)$ & $(0.041)$ & $(0.617)$ & $(0.733)$ & & & \\
\hline Regulated industry & $0.490^{* *}$ & $0.644^{* *}$ & 0.223 & 0.164 & 0.0375 & // & [0.0382] \\
\hline & $(0.039)$ & $(0.025)$ & $(0.713)$ & $(0.790)$ & & & \\
\hline Technology industry & $-0.681 * *$ & $-0.768 * * *$ & $-1.394 * * *$ & $-1.508 * * *$ & -0.3445 & // & {$[-0.3067]$} \\
\hline & $(0.014)$ & $(0.007)$ & $(0.001)$ & $(0.001)$ & & & \\
\hline Strong anti-takeover state & -0.019 & -0.076 & -0.303 & -0.511 & -0.1167 & // & {$[-0.1090]$} \\
\hline & $(0.945)$ & $(0.810)$ & $(0.578)$ & $(0.347)$ & & & \\
\hline M\&A liquidity index & $0.493 * * *$ & $0.360^{* *}$ & $-1.311^{* *}$ & $-1.726 * * *$ & -0.3943 & // & {$[-0.0543]$} \\
\hline & $(0.001)$ & $(0.037)$ & $(0.040)$ & $(0.006)$ & & & \\
\hline Buyout activity & 0.778 & 1.121 & 1.224 & 1.020 & 0.2330 & // & {$[0.0530]$} \\
\hline & $(0.344)$ & $(0.269)$ & $(0.476)$ & $(0.553)$ & & & \\
\hline Economic recession & $0.718 * *$ & $0.605^{*}$ & 0.204 & 0.049 & 0.0113 & // & [0.0113] \\
\hline
\end{tabular}




\begin{tabular}{|c|c|c|c|c|c|c|c|}
\hline & $(0.023)$ & $(0.093)$ & $(0.783)$ & $(0.945)$ & & & \\
\hline \multirow[t]{2}{*}{ Internet bubble deflation } & -0.368 & -0.510 & -0.481 & -0.167 & -0.0382 & $/ /$ & {$[-0.0378]$} \\
\hline & $(0.364)$ & $(0.284)$ & $(0.512)$ & $(0.811)$ & & & \\
\hline \multirow[t]{2}{*}{ Std. dev. of net income } & & $0.262 * *$ & -0.050 & -0.084 & -0.0193 & $/ /$ & {$[-0.0189]$} \\
\hline & & $(0.026)$ & $(0.797)$ & $(0.637)$ & & & \\
\hline \multirow[t]{2}{*}{ Discretionary accruals } & & & 0.307 & 0.261 & 0.0596 & // & [0.0054] \\
\hline & & & $(0.887)$ & $(0.903)$ & & & \\
\hline \multirow[t]{2}{*}{ Std. dev. of discretionary accruals } & & & -0.799 & -0.982 & -0.2243 & $/ /$ & {$[-0.0190]$} \\
\hline & & & $(0.724)$ & $(0.675)$ & & & \\
\hline \multirow[t]{2}{*}{ Avg. institutional ownership } & & 0.351 & 1.105 & 0.960 & 0.2194 & $/ /$ & {$[0.0600]$} \\
\hline & & $(0.501)$ & $(0.235)$ & $(0.318)$ & & & \\
\hline \multirow[t]{2}{*}{ Number of analysts } & & 0.001 & 0.020 & 0.014 & 0.0033 & $/ /$ & {$[0.0197]$} \\
\hline & & $(0.981)$ & $(0.496)$ & $(0.628)$ & & & \\
\hline \multirow[t]{2}{*}{ Altman's Z-score } & & & $0.035^{*}$ & 0.033 & 0.0075 & // & {$[0.0526]$} \\
\hline & & & $(0.090)$ & $(0.152)$ & & & \\
\hline \multirow[t]{2}{*}{ Interest coverage } & & & -0.003 & -0.003 & -0.0006 & // & {$[-0.0734]$} \\
\hline & & & $(0.330)$ & $(0.318)$ & & & \\
\hline \multirow[t]{2}{*}{ Liquidity ratio } & & & -0.114 & -0.094 & -0.0215 & // & {$[-0.0051]$} \\
\hline & & & $(0.917)$ & $(0.932)$ & & & \\
\hline \multirow[t]{2}{*}{ LT debt / EBITDA } & & 0.020 & -0.018 & -0.023 & -0.0053 & // & {$[-0.0248]$} \\
\hline & & $(0.333)$ & $(0.457)$ & $(0.402)$ & & & \\
\hline \multirow[t]{2}{*}{ BHAR prior year } & & 0.218 & $0.454^{*}$ & 0.341 & 0.0779 & // & {$[0.0458]$} \\
\hline & & $(0.330)$ & $(0.092)$ & $(0.240)$ & & & \\
\hline \multirow[t]{2}{*}{ Only cash payment } & & & & -0.096 & -0.0219 & // & {$[-0.0218]$} \\
\hline & & & & $(0.755)$ & & & \\
\hline \multirow[t]{2}{*}{ Tender } & & & & $-1.018 * * *$ & -0.2325 & $/ /$ & {$[-0.2159]$} \\
\hline & & & & $(0.006)$ & & & \\
\hline Intercept & Yes & Yes & Yes & Yes & & & \\
\hline Pseudo R2 & 0.209 & 0.214 & 0.177 & 0.203 & & & \\
\hline $\mathrm{N}$ & 625 & 563 & 245 & 245 & & & \\
\hline
\end{tabular}

The table presents Logit models on the Probability of Auction. We classify acquisitions as Auction or Negotiation based on the total number of bidders before the announcement of the acquisition. Variable definitions are in Appendix A. Inferences are based on White (1980) standard errors corrected for within-industry and year dependence. The asterisks, $* * * \mathrm{p}<0.01, * * \mathrm{p}<0.05, * \mathrm{p}<0.1$, describe the significance level of the coefficients (2-tailed tests unless a prediction is made). Model 4 presents the marginal effects and the changes in Predicted Probability: 0->1: change in predicted probability as $\mathrm{x}$ changes from 0 to 1 in binary variables. -+sd/2: change in predicted probability as $\mathrm{x}$ changes from $1 / 2$ standard dev. below base to $1 / 2$ standard deviation above in continuous variables, holding the other variables at their means.

\subsection{The Impact of Method-of-sale on (Bidder and Target) Shareholders' Wealth}

We model the multivariate relation between (bidder and target) shareholders' wealth effects and both the method-of-sale and adverse selection risk with the following model to test $\mathrm{H} 2$ :

Shareholders' Wealth $_{i}=f($ Auction, Target Initiation, Auction $*$ Target Initiation, Control Variables $)$

To estimate the impact of Method-of-sale on shareholders' wealth, we use three proxies: long-term (LT) total surplus 
gain, Bidder's LT return, and Target's LT return. We calculate LT abnormal returns using the Fama French 3-factor model (Boone \& Mulherin, 2007b) for the period beginning 63 days before to 126 days after the announcement date (LT returns) or to completion or withdrawal date, whichever occurs first. (Note 7) We use LT returns to avoid issues with arbitrage spreads that exist with ST returns. LT returns better capture the value created in the deal by looking at the entire time the deal has transpired or until four months post-announcement and they avoid sensitivity to earlier abnormal price movements related to transaction rumors prior to the Announcement Date in SDC (Mulherin \& Simsir, 2015). We calculate the LT total surplus gain of the acquisition as the cumulative abnormal dollar return based on the LT returns for the target and the bidder divided by the sum of the market capitalization of the target and the bidder as estimated 63 days before the announcement date. We focus on $L T$ returns because they provide a more complete picture of the wealth changes that an acquisition accrues to both the target and the bidder. More importantly, examining LT returns allows us to examine the total surplus gain in a twofold manner. First, LT returns include the run-up premium before the public announcement of the acquisition (Schwert 1996, 2000; Betton et al., 2014) and, second, they exclude the effect of a muffled market reaction as reflected in arbitrage spreads (Brown \& Raymond, 1986; Mitchell, Pulvino, \& Stafford, 2004; Denis \& Macias, 2013). (Note 8) Prior research including Bradley et al. (1988) and Dittmar et al. (2012) use this measure of long-term returns. Our variables of interest are Auction and Target initiation.

Table 4 presents the results of the OLS model specified in equation (3) examining the impact of auction and target initiation on the LT total surplus gain (panel A), bidder LT returns (panel B), and target LT returns (panel C). Model (1) uses the entire sample, while models (2) and (3) split the sample into target initiated and non-target-initiated transactions, respectively.

Table 4 Model (1) of Panel A, shows a positive and significant coefficient on Auction suggesting that total surplus gain is higher in auctions relative to negotiations. To further examine the positive relation between auctions and total surplus gain, models (2-3) examine the impact of Target initiation. The results presented in model (2), show a positive significant coefficient on Auction and a significantly negative coefficient on Target initiation corroborating the notion that markets recognize value creation in auctions but discounts them when targets initiate the transactions, consistent with $\mathrm{H} 2$.

When we split the sample by Target initiation in Models (2-3), effectively interacting all variables in our model with the transaction initiator, we find that the Auction coefficient is positive and significant only when targets do not initiate the transaction, a result that highlights the importance of the target initiation condition.

Table 4 Model (1) of Panel B also shows a positive and significant coefficient on Auction suggesting that bidder LT returns are higher in auctions relative to negotiations. Examining the impact of target initiation models (2-3) show that the positive coefficient on Auction is significant only when targets do not initiate the transaction, corroborating the notion that the market rewards bidders in auctions when the targets do not initiate the transactions, consistent with $\mathrm{H} 2$.

Finally, Panel C of Table 4 presents the results for target's LT returns. The results on target initiation in model (1) are similar to those reported in panel B (bidder returns) in that we find a negative coefficient on Target initiation indicating a penalty related to adverse selection risk, again consistent with $\mathrm{H} 2$. However, consistent with Boone and Mulherin (2007a), we do not find a significant coefficient on Auction, in contrast with the results related to bidders' returns.

Collectively, the results reported in Table 4 suggest that bidder shareholders benefit from pursuing an auction when the target does not initiate the sale, consistent with expected positive returns to the winning bidder in a strategic equilibrium of auctions (Dasgupta \& Hansen, 2007). In contrast, when the target initiates the transaction, there are significantly lower LT returns for both bidders and targets due to high adverse selection risk, consistent with Akerlof's (1970) "lemon discount" and our H2 prediction. 
Table 4. The Impact of Target Initiation and the Method-of-sale on Wealth Effects - OLS Regression

Table 4 Panel A. LT total surplus gain

\begin{tabular}{|c|c|c|c|}
\hline Subsample & Whole sample & Target initiation & $\begin{array}{l}\text { Non-Target } \\
\text { initiation }\end{array}$ \\
\hline Model & (1) & (2) & (3) \\
\hline \multirow[t]{2}{*}{ Auction } & $0.034^{*}$ & 0.011 & $0.050 * *$ \\
\hline & $(0.054)$ & $(0.783)$ & $(0.030)$ \\
\hline \multirow[t]{2}{*}{ Target initiation } & $-0.028 * *$ & & \\
\hline & $(0.039)$ & & \\
\hline \multirow[t]{2}{*}{ Log (Mkt. value assets) } & 0.006 & -0.019 & $0.025 * * *$ \\
\hline & $(0.434)$ & $(0.101)$ & $(0.008)$ \\
\hline \multirow[t]{2}{*}{ ROA (EBITDA/assets) } & -0.015 & 0.047 & $-0.093 * *$ \\
\hline & $(0.588)$ & $(0.347)$ & $(0.024)$ \\
\hline \multirow[t]{2}{*}{$\log ($ Tobin’s Q) } & 0.026 & 0.050 & 0.017 \\
\hline & $(0.299)$ & $(0.223)$ & $(0.519)$ \\
\hline \multirow[t]{2}{*}{ R\&D-to-sales } & $-0.099 *$ & -0.120 & -0.088 \\
\hline & $(0.089)$ & $(0.281)$ & $(0.166)$ \\
\hline \multirow[t]{2}{*}{ LT leverage } & 0.003 & 0.058 & -0.049 \\
\hline & $(0.942)$ & $(0.430)$ & $(0.372)$ \\
\hline \multirow[t]{2}{*}{ Log (Bidder mkt. value assets) } & $-0.016 * * *$ & 0.000 & $-0.031 * * *$ \\
\hline & $(0.003)$ & $(0.987)$ & $(0.000)$ \\
\hline \multirow[t]{2}{*}{ Bidder ROA (EBITDA/assets) } & -0.157 & 0.015 & $-0.442 * *$ \\
\hline & $(0.131)$ & $(0.937)$ & $(0.043)$ \\
\hline \multirow[t]{2}{*}{ Bidder log(Tobin’s Q) } & -0.026 & -0.065 & 0.019 \\
\hline & $(0.143)$ & $(0.124)$ & $(0.544)$ \\
\hline \multirow[t]{2}{*}{ Bidder R\&D-to-sales } & -0.269 & -0.112 & $-0.416^{*}$ \\
\hline & $(0.290)$ & $(0.652)$ & $(0.091)$ \\
\hline \multirow[t]{2}{*}{ Regulated industry } & $-0.056^{* *}$ & $-0.046^{*}$ & $-0.076^{* *}$ \\
\hline & $(0.032)$ & $(0.097)$ & $(0.036)$ \\
\hline \multirow[t]{2}{*}{ Technology industry } & 0.030 & 0.018 & 0.033 \\
\hline & $(0.187)$ & $(0.590)$ & $(0.242)$ \\
\hline \multirow[t]{2}{*}{ Strong anti-takeover state } & -0.003 & -0.016 & 0.012 \\
\hline & $(0.853)$ & $(0.439)$ & $(0.652)$ \\
\hline \multirow[t]{2}{*}{ M\&A liquidity index } & 0.008 & 0.022 & 0.011 \\
\hline & $(0.533)$ & $(0.221)$ & $(0.591)$ \\
\hline \multirow[t]{2}{*}{ Buyout activity } & 0.187 & 0.192 & 0.197 \\
\hline & $(0.283)$ & $(0.420)$ & $(0.143)$ \\
\hline \multirow[t]{2}{*}{ Economic recession } & $-0.052 *$ & -0.056 & -0.009 \\
\hline & $(0.088)$ & $(0.237)$ & $(0.734)$ \\
\hline \multirow[t]{2}{*}{ Internet bubble deflation } & 0.032 & 0.053 & -0.005 \\
\hline & $(0.670)$ & $(0.616)$ & $(0.948)$ \\
\hline
\end{tabular}




\begin{tabular}{llll} 
Challenged deal & 0.029 & -0.055 & 0.047 \\
Tender & $(0.366)$ & $(0.508)$ & $(0.191)$ \\
& -0.013 & $-0.086^{* *}$ & 0.038 \\
Diversified deal & $(0.568)$ & $(0.013)$ & $(0.226)$ \\
& -0.037 & -0.036 & -0.044 \\
Only cash payment & $(0.160)$ & $(0.343)$ & $(0.143)$ \\
& -0.025 & -0.045 & -0.017 \\
Hostile-Unsolicited & $(0.232)$ & $(0.214)$ & $(0.520)$ \\
& 0.001 & - & -0.040 \\
Intercept & $(0.966)$ & - & $(0.261)$ \\
Adjusted R2 & Yes & Yes & Yes \\
$\mathrm{N}$ & 0.097 & 0.099 & 0.115 \\
\hline
\end{tabular}

Table 4 Continued - Panel B. Bidder's LT returns

\begin{tabular}{|c|c|c|c|}
\hline Subsample & Whole sample & Target initiation & $\begin{array}{l}\text { Non-Target } \\
\text { initiation }\end{array}$ \\
\hline Model & (1) & (2) & (3) \\
\hline \multirow[t]{2}{*}{ Auction } & $0.081 * * *$ & 0.063 & $0.106^{* *}$ \\
\hline & $(0.001)$ & $(0.105)$ & $(0.018)$ \\
\hline \multirow[t]{2}{*}{ Target initiation } & $-0.040 * *$ & & \\
\hline & $(0.048)$ & & \\
\hline \multirow[t]{2}{*}{ Log (Mkt. value assets) } & -0.009 & $-0.033^{*}$ & 0.011 \\
\hline & $(0.445)$ & $(0.099)$ & $(0.522)$ \\
\hline \multirow[t]{2}{*}{ ROA (EBITDA/assets) } & 0.021 & $0.200 * *$ & $-0.128 *$ \\
\hline & $(0.701)$ & $(0.019)$ & $(0.086)$ \\
\hline \multirow[t]{2}{*}{$\log$ (Tobin’s Q) } & 0.068 & $0.142 *$ & 0.038 \\
\hline & $(0.173)$ & $(0.074)$ & $(0.481)$ \\
\hline \multirow[t]{2}{*}{ R\&D-to-sales } & $-0.259 * *$ & -0.284 & $-0.228 * *$ \\
\hline & $(0.022)$ & $(0.211)$ & $(0.047)$ \\
\hline \multirow[t]{2}{*}{ LT leverage } & 0.023 & 0.063 & -0.017 \\
\hline & $(0.743)$ & $(0.606)$ & $(0.871)$ \\
\hline \multirow[t]{2}{*}{ Log (Bidder mkt. value assets) } & -0.016 & 0.004 & $-0.035^{* *}$ \\
\hline & $(0.133)$ & $(0.851)$ & $(0.029)$ \\
\hline \multirow[t]{2}{*}{ Bidder ROA (EBITDA/assets) } & $-0.393 *$ & -0.088 & $-0.789 * *$ \\
\hline & $(0.053)$ & $(0.798)$ & $(0.021)$ \\
\hline \multirow[t]{2}{*}{ Bidder log(Tobin’s Q) } & -0.046 & $-0.163 *$ & 0.050 \\
\hline & $(0.257)$ & $(0.060)$ & $(0.412)$ \\
\hline \multirow[t]{2}{*}{ Bidder R\&D-to-sales } & -0.387 & 0.024 & -0.727 \\
\hline & $(0.371)$ & $(0.939)$ & $(0.147)$ \\
\hline \multirow[t]{2}{*}{ Regulated industry } & $-0.085 * *$ & $-0.080^{*}$ & -0.099 \\
\hline & $(0.042)$ & $(0.079)$ & $(0.143)$ \\
\hline
\end{tabular}




\begin{tabular}{|c|c|c|c|}
\hline Technology industry & $\begin{array}{l}0.076 \\
(0.115)\end{array}$ & $\begin{array}{l}0.082 \\
(0.260)\end{array}$ & $\begin{array}{l}0.067 \\
(0.261)\end{array}$ \\
\hline \multirow[t]{2}{*}{ Strong anti-takeover state } & -0.025 & -0.039 & 0.007 \\
\hline & $(0.485)$ & $(0.319)$ & $(0.895)$ \\
\hline \multirow[t]{2}{*}{ M\&A liquidity index } & 0.019 & 0.029 & 0.031 \\
\hline & $(0.461)$ & $(0.306)$ & $(0.506)$ \\
\hline \multirow[t]{2}{*}{ Buyout activity } & 0.454 & 0.576 & $0.427 *$ \\
\hline & $(0.233)$ & $(0.307)$ & $(0.060)$ \\
\hline \multirow[t]{2}{*}{ Economic recession } & $-0.102 *$ & -0.091 & -0.049 \\
\hline & $(0.092)$ & $(0.344)$ & $(0.329)$ \\
\hline \multirow[t]{2}{*}{ Internet bubble deflation } & 0.012 & -0.039 & -0.009 \\
\hline & $(0.933)$ & $(0.831)$ & $(0.943)$ \\
\hline \multirow[t]{2}{*}{ Challenged deal } & 0.039 & -0.150 & 0.078 \\
\hline & $(0.532)$ & $(0.310)$ & $(0.225)$ \\
\hline \multirow[t]{2}{*}{ Tender } & -0.007 & $-0.113^{*}$ & 0.059 \\
\hline & $(0.855)$ & $(0.065)$ & $(0.396)$ \\
\hline \multirow[t]{2}{*}{ Diversified deal } & -0.075 & -0.058 & -0.096 \\
\hline & $(0.158)$ & $(0.415)$ & $(0.125)$ \\
\hline \multirow[t]{2}{*}{ Only cash payment } & -0.062 & -0.091 & -0.048 \\
\hline & $(0.159)$ & $(0.141)$ & $(0.371)$ \\
\hline \multirow[t]{2}{*}{ Hostile-Unsolicited } & 0.008 & . & -0.041 \\
\hline & $(0.902)$ & . & $(0.522)$ \\
\hline Intercept & Yes & Yes & Yes \\
\hline Adjusted R2 & 0.086 & 0.086 & 0.085 \\
\hline $\mathrm{N}$ & 563 & 262 & 301 \\
\hline
\end{tabular}

Table 4 Continued - Panel C. Target's LT returns

\begin{tabular}{llll}
\hline Subsample & \multicolumn{1}{c}{ Whole sample } & Target initiation & $\begin{array}{c}\text { Non-Target } \\
\text { initiation }\end{array}$ \\
Model & $(1)$ & $(2)$ & $(3)$ \\
\hline Auction & 0.041 & -0.021 & 0.042 \\
& $(0.318)$ & $(0.721)$ & $(0.439)$ \\
Target initiation & $-0.082^{* * *}$ & & \\
& $(0.005)$ & & \\
Log (Mkt. value assets) & $-0.078^{* * *}$ & $-0.101^{* * *}$ & $-0.058^{* * *}$ \\
& 0.000 & $(0.003)$ & $(0.002)$ \\
ROA (EBITDA/assets) & 0.034 & 0.062 & -0.116 \\
& $(0.854)$ & $(0.811)$ & $(0.519)$ \\
$\log$ (Tobin's Q) & $-0.142^{* * *}$ & $-0.178^{* *}$ & $-0.102^{*}$ \\
& $(0.002)$ & $(0.014)$ & $(0.056)$ \\
R\&D-to-sales & 0.044 & -0.170 & 0.296 \\
& $(0.749)$ & $(0.189)$ & $(0.156)$
\end{tabular}




\begin{tabular}{|c|c|c|c|}
\hline LT leverage & $\begin{array}{l}0.072 \\
(0.422)\end{array}$ & $\begin{array}{l}0.191 \\
(0.196)\end{array}$ & $\begin{array}{l}-0.056 \\
(0.613)\end{array}$ \\
\hline \multirow[t]{2}{*}{ Log (Bidder mkt. value assets) } & $0.046 * * *$ & $0.048^{* *}$ & $0.038 * * *$ \\
\hline & $(0.003)$ & $(0.030)$ & $(0.007)$ \\
\hline \multirow[t]{2}{*}{ Bidder ROA (EBITDA/assets) } & 0.214 & $0.929^{* *}$ & $-0.620 * *$ \\
\hline & $(0.223)$ & $(0.014)$ & $(0.033)$ \\
\hline \multirow[t]{2}{*}{ Bidder log(Tobin’s Q) } & 0.012 & -0.024 & 0.054 \\
\hline & $(0.779)$ & $(0.769)$ & $(0.335)$ \\
\hline \multirow[t]{2}{*}{ Bidder R\&D-to-sales } & -0.307 & 0.087 & $-0.735^{* *}$ \\
\hline & $(0.390)$ & $(0.745)$ & $(0.030)$ \\
\hline \multirow[t]{2}{*}{ Regulated industry } & -0.082 & 0.019 & $-0.209 * * *$ \\
\hline & $(0.199)$ & $(0.804)$ & $(0.002)$ \\
\hline \multirow[t]{2}{*}{ Technology industry } & 0.027 & 0.058 & -0.010 \\
\hline & $(0.446)$ & $(0.351)$ & $(0.854)$ \\
\hline \multirow[t]{2}{*}{ Strong anti-takeover state } & 0.044 & 0.062 & 0.048 \\
\hline & $(0.460)$ & $(0.391)$ & $(0.485)$ \\
\hline \multirow[t]{2}{*}{ M\&A liquidity index } & -0.002 & 0.009 & 0.004 \\
\hline & $(0.920)$ & $(0.775)$ & $(0.931)$ \\
\hline \multirow[t]{2}{*}{ Buyout activity } & $0.508^{* *}$ & $0.536^{* *}$ & $0.553^{* *}$ \\
\hline & $(0.013)$ & $(0.035)$ & $(0.042)$ \\
\hline \multirow[t]{2}{*}{ Economic recession } & -0.077 & -0.024 & -0.051 \\
\hline & $(0.350)$ & $(0.806)$ & $(0.680)$ \\
\hline \multirow[t]{2}{*}{ Internet bubble deflation } & -0.093 & -0.103 & -0.158 \\
\hline & $(0.362)$ & $(0.377)$ & $(0.290)$ \\
\hline \multirow[t]{2}{*}{ Challenged deal } & -0.018 & -0.007 & -0.024 \\
\hline & $(0.786)$ & $(0.975)$ & $(0.754)$ \\
\hline \multirow[t]{2}{*}{ Tender } & 0.031 & -0.068 & $0.102^{*}$ \\
\hline & $(0.588)$ & $(0.514)$ & $(0.093)$ \\
\hline \multirow[t]{2}{*}{ Diversified deal } & 0.006 & 0.012 & -0.022 \\
\hline & $(0.879)$ & $(0.789)$ & $(0.657)$ \\
\hline \multirow[t]{2}{*}{ Only cash payment } & -0.026 & $-0.087^{*}$ & 0.022 \\
\hline & $(0.467)$ & $(0.097)$ & $(0.704)$ \\
\hline \multirow[t]{2}{*}{ Hostile-Unsolicited } & -0.032 & . & -0.084 \\
\hline & $(0.685)$ & . & $(0.347)$ \\
\hline Intercept & Yes & Yes & Yes \\
\hline Adjusted R2 & 0.097 & 0.153 & 0.083 \\
\hline $\mathrm{N}$ & 563 & 262 & 301 \\
\hline
\end{tabular}

This table presents OLS regressions on LT total surplus gain (Panel A), Bidder's LT returns (Panel B), Target's LT returns (Panel C) in the acquisitions. LT returns are defined as the cumulative abnormal returns from 63 days before the announcement date to 126 days after the announcement date (or completion date if earlier) calculated using the Fama-French 3- factor model. The LT total surplus gain of the acquisition is calculated as the cumulative abnormal dollar return based on the LT returns for the target and the bidder divided by the sum of the market capitalization of the target and the bidder as estimated 63 days before the announcement date. Variable definitions are in Appendix A. 
We report the coefficients and the p-values in parentheses. Inferences are based on White (1980) standard errors corrected for within-industry and year dependence. The asterisks, *** $\mathrm{p}<0.01, * * \mathrm{p}<0.05, * \mathrm{p}<0.1$, describe the significance level of the coefficients (2-tailed tests unless a prediction is made).

\subsection{Endogeneity Concerns}

Our multivariate analysis in Table 4 is based on OLS estimation. As a sensitivity test, we estimate the models using seemingly unrelated regressions (SUR) (Zellner, 1962; Greene, 2003; Wooldridge, 2010), where the endogenous variables are Target initiation and Auction combined with LT total surplus gain, bidders' LT returns, and targets' $L T$ returns, respectively. (Note 9) The SUR consists of a set of equations in which the error terms in the regression equations are correlated. In any test that aims to control for endogeneity bias, the selection of adequate instruments is problematic. To alleviate this concern and to gain efficiency in the estimation, we use SUR, which combines information from the errors of different equations. The regressions estimated in the simultaneous system are those specified in equations (1), (2) and (3) above. We use the bidder and deal controls from Table 4 as the exogenous variables in the model of wealth changes (i.e., total surplus gain, bidder's LT returns, and target's LT returns). The SUR estimation results (not tabulated) are consistent with the OLS results reported in Table 4, which suggests that Endogeneity bias is not a serious concern. Importantly, while we cannot completely rule out simultaneity completely, it does not seem to invalidate our main OLS inferences.

\section{Conclusion and Summary of Findings}

\subsection{Summary of Statistical Tests}

The purpose of this study is to examine target-initiation strategic choice using the auction forum to first identify if target-initiated auction M\&A deals are associated with higher adverse selection risk, and second, to determine the detrimental wealth effects of that choice for both target and buyer-bidder, which ties to our first two research questions and corresponding hypotheses. Akerlof's (1970) theory of the market for lemons explains our particular M\&A setting well and we employ his framework as our theoretical lens with support from the ethics literature.

To summarize our specific findings, we uncover heterogeneity in the pre-announcement process by identifying the party that initiates the transaction. We then show direct evidence that targets that initiate the transaction convey higher levels of adverse selection risk, which in turn impacts both the observed method-of-sale and long-term wealth changes. Our analyses reveal that targets initiate $45 \%$ of the transactions in our sample, and that all else equal, if the target initiates the sale of the firm, the predicted probability of an auction is, depending on the specification, between $25 \%$ and $45 \%$ greater than when a target does not initiate the transaction. Consistent with potentially higher information asymmetry in target-initiated auctions, we also find that the window for due diligence before the acquisition announcement is substantially shorter for these transactions. These findings answer our first research question and support H1, respectively. These findings are not only statistically significant but also have noteworthy practical importance.

When we control for target initiation, we find that selling through an auction is associated with higher total surplus gains and bidder long-term abnormal returns (LT returns). Additionally, a target-initiated transaction reduces the changes in wealth for both bidders and targets. The highest target gains and long-term bidder returns occur in auctions when the target does not initiate. These results hold in SUR (seemingly unrelated regression) analysis where we attempt to control for the simultaneity of the decision to sell, the method-of-sale decision and the expected wealth effects. We show that the economic impact of target initiation is not simply a manifestation of financial distress or poorly performing firms choosing to sell. Instead, information asymmetry seems to be the main driver for the target decision to initiate the sale, consistent with Akerlof's theory. Finally, we show that target auction initiation is a unique indicator of information asymmetry that is discounted by the market, and suppresses wealth effects for both bidder and target, which Akerlof's theory suggests is a societal reputational cost for perceived dishonesty (Akerlof, 1970). When the target strategically initiates the auction method of sale, presumably to gain information advantages over the bidder, the bidder apparently sees through the target's unethical behavior, consistent with a target "lemons" societal reputation effect that causes both the target and bidder to suffer wealth discounts. The finding is consistent with Kulkarni (2000, pp. 224), who argues that "significant payoff losses [result] to both parties if either one behaves opportunistically." Conversely, the combined and individual gains from acquisitions are larger when adverse selection risk is lower. These results highlight the importance of considering private information factors when examining the relation between the method-of-sale and both bidder and target shareholder wealth changes. Collectively, these results answer the second research question posed at the outset and strongly support $\mathrm{H} 2$. These findings have significant business and societal managerial implications that underscore that both M\&A bidders and targets benefit when target adverse selection risk is decreased. Below we discuss these implications, as well as study 
contributions and limitations. A key takeaway of the study is that target-initiated auction M\&A dynamics may involve adverse selection concerns and opportunistic behavior.

\subsection{Managerial Implications, Contributions, and Limitations}

Based on our empirical findings, we suggest that M\&A advisors become more pro-active to constrain target opportunistic behavior, which may be a pragmatic step given that they organize the M\&A auctions and observe repeat bidders and target firms. Denis and Macias (2013), and Macias and Moeller (2016) discuss M\&A contractual innovations called material adverse change (MAC) clauses that relate to material adverse events (MAEs) that bidders can employ to either terminate an acquisition or possibly renegotiate an acquisition when an MAE is uncovered. As a recent example, in the Delaware court case Akorn v. Fresenius (Del. 2018), the court ruled that an MAE occurred that allowed the acquirer to terminate the M\&A because the target's earnings declined $86 \%$ within one year of the agreement (Weinstein, de Wied, \& Kagan, 2020). It is possible that financial deception played a role in this case. Collectively, these contractual innovation strategies should reduce target adverse selection risk. However, they all suffer from the same limitation: they are transaction specific, meaning that these remedies are short-term oriented and are also generally costly to both bidder and target. Nevertheless, Denis and Macias (2013) and Macias and Moeller (2016) are tangentially related to our inquiry and indirectly support our findings.

We posit that it is more efficient for target firms to address Akerlof's (1970) "lemons" problem of adverse selection risk by enhancing target firm long-term ethical reputation and value in the marketplace by conducting business in a manner that reflects integrity and ethics. The "lemons" problem stems from a lack of trust between buyer and seller, which manifests itself as a societal cost of dishonesty (Akerlof, 1970) such as we report where both target and buyer suffer economic loss due to market failure. This market failure provides an excellent empirical example of why Erhard and Jensen (2014) argue that assessing integrity in finance and accounting research is essential, because target firms that have a history of contracting fairly and equitably will be trusted by the market, decreasing target adverse selection risk and related transaction costs. Jones (1995) summarizes that opportunistic managers may be unable to forgo the perceived short-term benefits of unethical behavior, in contrast to moral managers who invest long-term to create and maintain a culture characterized by trust and fair dealing. An ethical business reputation is "difficult to fake", because it is tested continuously by marketplace interactions and transactions (Jones, 1995, pp. 420).

Kulkarni (2000) suggests that trust is in many ways the converse of opportunism and adverse selection that we contend can remedy the M\&A issue we study at both the micro-business and macro-societal and reputation levels. Organizations that promote trust in business dealings, including acquisition negotiations, build a positive and ethical reputation in the societal marketplace (Jones, 1995), in contrast to firms that attempt to leverage adverse selection in the short-term, as described by the lemons model. Building a firm reputation of trust, integrity and ethical behavior is the antidote to the "lemons" problem that we identify, and likely produces long-term economic gains for target and bidder alike while also providing a partial remedy for market failure. Pragmatically, Arce (2004, pp. 263) asserts that "[e]thical behavior can reduce transaction, contracting, policing, and enforcement costs... and policies that promote honesty." He notes further (pp. 264) that "[a] reputation for candor and responsibility is a commercial asset - on the enterprise's balance sheet it may be called goodwill." Relatedly, Katmon and Al Farooque (2017) suggest that firms that wish to reduce adverse selection risk should build strong internal governance structures that discourage inappropriate earnings management while enhancing financial disclosure transparency. These pragmatic strategies may assist a moral target by sending ethical reputation cues to segregate itself from targets that instead pursue hidden information strategies (Macias \& Moeller, 2016). Collectively, the literature again illustrates why Erhard and Jensen (2014) argue that assessing integrity in accounting and finance research is essential.

The study substantially contributes to the ethics literature in general, and to the sparse ethics literature dealing with M\&A activity, in particular. Our theory-driven study addresses a noteworthy gap in the literature, since we are unaware of any ethics study that employs archival longitudinal data to assess acquisition bidder versus target adverse selection risk dynamics and resultant wealth effects. Together with Masulis and Simsir (2018), this study is also the only investigation we are aware of that empirically tests Akerlof's (1970) lemons model in the context of acquisition dynamics. The study also significantly contributes to the business acquisition literature in several additional ways. For example, we explain Dasgupta and Hansen's (2007) unknown factor associated with average minimal returns to bidders by controlling for the target-initiated auction method of sale. In addition, while we find a strong positive relationship between proxies of adverse selection risk and the likelihood of target initiation, our robustness tests suggest target-initiation itself is a unique indicator of information asymmetry in an acquisition environment, which is yet another contribution. Furthermore, our findings further elucidate why targets may have higher adverse selection risk, which provides empirical support for Masulis and Simsir's (2018) contentions. Finally, we prove empirically 
that non-target-initiated acquisitions drive auction wealth benefits, and that the target-initiated auction strategy is associated with significant economic wealth discounts, which was previously assumed but not proven by Boone and Mulherin (2009) and Aktas et al. (2010).

Although the present study significantly contributes to both the ethics and M\&A literatures, we acknowledge a sample period limitation. Specifically, our sample period ends before the great recession. Due to the nature and severity of the great recession, as well as the impact on M\&A activity, we did not extend the sample period to these years. We also note the time-consuming acquisition identification hand collection process that we describe in the sample selection discussion to explain why we did not extend our sample period further. We deem our eight-year sample period as sufficient to identify the robust and noteworthy findings we report. Finally, the study may also have self-selection bias issues due to the nature of the study.

Future research should investigate whether target firms with ethical reputations, who nevertheless strategically choose the auction method of sale, suffer market discounts merely because of the method of sale - initiation interaction. Do target firms that provide transparent financial disclosures and pursue socially responsible activities reap market premiums as the theory suggests? Can companies engage in M\&A to escape, evade, or avoid CSR issues? Are information asymmetries exacerbated when buyers and sellers are from different geo-political boundaries? These issues provide possible avenues for future research.

\section{References}

Akerlof, G. (1970). The market for 'lemons': Quality uncertainty and the market mechanism. Quarterly Journal of Economics, 84, 488-500. https://doi.org/10.2307/1879431

Aktas, N., de Bodt, E., \& Roll, R. (2010). Negotiations under the threat of an auction. Journal of Financial Economics, 98, 241-255. https://doi.org/10.1016/j.jfineco.2010.06.002

Altman, E. I. (1968). Financial ratios, discriminant analysis and the prediction of corporate bankruptcy. Journal of Finance, 23, 589-609. https://doi.org/10.2307/2978933

Arce, D. G. (2004). Conspicuous by its absence: Ethics and managerial economics. Journal of Business Ethics, 54, 261-277. https://doi.org/10.1007/s10551-004-1773-5

Arrow, K. J. (1985). The economics of agency. In J.W. Pratt \& R.J. Zeckhauser (Eds.), Principals and agents: The structure of business. Boston: Harvard Business School.

Ashbaugh, H., Collins, D., \& LaFond, R. (2006). The effects of corporate governance on firms' credit ratings. Journal of Accounting and Economics, 42, 203-243. https://doi.org/10.1016/j.jacceco.2006.02.003

Betton, S., Eckbo, B. E., Thompson, R., \& Thorburn, K. (2014). Merger negotiations with stock market feedback. Journal of Finance, 69, 1705-1745. https://doi.org/10.2139/ssrn.1835073

Bhojraj, S., \& Sengupta, P. (2003). Effect of corporate governance on bond ratings and yields: The role of institutional investors and outside directors. Journal of Business, 76, 455-475. https://doi.org/10.1086/344114

Boone, A., \& Mulherin, H. (2007a). How are firms sold? Journal of Finance, 62, 847-875. https://doi.org/10.1111/j.1540-6261.2007.01225.x

Boone, A., \& Mulherin, H. (2007b). Do termination provisions truncate the takeover bidding process? Review of Financial Studies, 20, 461-489. https://doi.org/10.1093/rfs/hhl009

Boone, A., \& Mulherin, H. (2008). Do auctions induce a winner's curse? New evidence from the corporate takeover market. Journal of Financial Economics, 89, 1-19. https://doi.org/10.1016/j.jfineco.2007.08.003

Boone, A., \& Mulherin, H. (2009). Is there one best way to sell a company? Auctions versus negotiations and controlled sales. Journal of Applied Corporate Finance, 21, 28-37. https://doi.org/10.1111/j.1745-6622.2009.00237.x

Boston Globe. (2004). Mergers \& acquisitions: 'Virtual data rooms' speed up deals: Digitizing deal data is proving a good way to reduce the time and expense of completing due diligence. Bank Technology News, June 01, 2004, Factiva Dow Jones.

Bradley, M., Desai, A., \& Kim, E. H. (1988). Synergistic gains from corporate acquisitions and their division between the stockholders of target and acquiring firms. Journal of Financial Economics, 21, 3-40. https://doi.org/10.1016/0304-405X(88)90030-X 
Brown, K. C., \& Raymond, M. V. (1986). Risk arbitrage and the prediction of successful corporate takeovers. Financial Management, 15, 54-63. https://doi.org/10.2307/3664844

Bulow, J., \& Klemperer, P. (1996). Auctions vs. negotiations. The American Economic Review, 86, 180-194.

Bulow, J., \& Klemperer, P. (2002). Prices and the winner's curse. RAND Journal of Economics, 33, 1-21. https://doi.org/10.2307/2696372

Bulow, J., \& Klemperer, P. (2009). Why do sellers (usually) prefer auctions? American Economic Review, 99, 1544-1575. https://doi.org/10.1257/aer.99.4.1544

Cantillon, E. (2008). The effect of bidders' asymmetries on expected revenue in auctions. Games and Economic Behavior, 62, 1-25. https://doi.org/10.1016/j.geb.2006.11.005

Christie, A. A., \& Zimmerman, J. L. (1994). Efficient and opportunistic choices of accounting procedures: corporate control contests. The Accounting Review, 69, 539-566. https://www.jstor.org/stable/248431

Cornett, M. M., Marcus, A. J., \& Tehranian, H. (2008). Corporate governance and pay-for-performance: The impact of earnings management. Journal of Financial Economics, 87, 357-373. https://doi.org/10.1016/j.jfineco.2007.03.003

Dasgupta, S., \& Hansen, R. (2007). Auctions in corporate finance in: Eckbo, B. Espen (Editor), Handbook of corporate finance: Empirical corporate finance. Elsevier, North-Holland, New York, 87-143. https://doi.org/10.1016/B978-0-444-53265-7.50017-2

Dechow, P., \& Dichev, I. (2002). The quality of accruals and earnings: The role of accrual estimation errors. The Accounting Review, 77, 35-59. https://doi.org/10.2308/accr.2002.77.s-1.35

Denis, D. J., \& Macias, A. J. (2013). Material adverse change clauses and acquisition dynamics. Journal of Financial and Quantitative Analysis, 48(3), 819-847. https://doi.org/10.1017/S0022109013000288

Dittmar, A., Li, D., \& Nain, A. (2012). It pays to follow the leader: acquiring targets picked by private equity. Journal of Financial and Quantitative Analysis, 47, 901-931. https://doi.org/10.1017/S0022109012000361

Erhard, W., \& Jensen, M. (2014). Putting integrity into finance: A purely positive approach. NBER Working Paper 19986. Cambridge, MA. https://doi.org/10.3386/w19986

Erickson, M., \& Wang, S. (1999). Earnings management by acquiring firms in stock for stock mergers. Journal of Accounting \& Economics, 27, 149-176. https://doi.org/10.1016/S0165-4101(99)00008-7

Fama, E. F., \& French, K. R. (1997). Industry costs of equity. Journal of Financial Economics, 43, 153-193. https://doi.org/10.1016/S0304-405X(96)00896-3

French, K. R., \& McCormick, R. E. (1984). Sealed bids, sunk costs, and the process of competition. Journal of Business, 57, 417-441. https://doi.org/10.1086/296273

Gong, G., Louis, H., \& Sun, A. (2008). Earnings management, lawsuits, and stock-for-stock acquirers' market performance. Journal of Accounting \& Economics, 46, 62-77. https://doi.org/10.1016/j.jacceco.2008.03.001

Greene, W. (2003). Econometric Analysis, 5th ed. New Jersey, Prentice Hall.

Guo, Z. Y., \& Lou, Y. (2017). The effect of sales and evidence from micro data. Research in World Economy, 8(1), 37. https://doi.org/10.5430/rwe.v8n1p37

Hansen, R. G. (2001). Auction of companies. Economic Inquiry, 39, 30-43. https://doi.org/10.1111/j.1465-7295.2001.tb00048.x

Herzel, L., \& Shepro, R. W. (1990). Bidders and targets: mergers and acquisitions in the U.S. Cambridge, MA, Basil Blackwell.

Hilbe, J. M. (2009). Logistic regression models, Chapman \& Hall/CRC Press. https://doi.org/10.1201/9781420075779

Hirshleifer, D., \& Png, I. P. L. (1989). Facilitation of competing bids and the price of a takeover target. The Review of Financial Studies, 2, 587-606. https://doi.org/10.1093/rfs/2.4.587

Hosmer, D. W., \& Lemeshow, S. (2000). Applied logistic regression analysis. Second Edition, New York, John Wiley and Sons, Inc. https://doi.org/10.1002/0471722146 
Jaffee, J., Keim, D., \& Westerfield, R. (1989). Earnings yields, market values and stock returns. Journal of Finance, 44, 135-148. https://doi.org/10.1111/j.1540-6261.1989.tb02408.x

Jones, T. M. (1995). Instrumental stakeholder theory: A synthesis of ethics and economics. Academy of Management Review, 20(2), 404-437. https://doi.org/10.5465/amr.1995.9507312924

Kaplan, S., Roush, P. B., \& Thorne, L. (2007). Anderson and the market for lemons in audit reports. Journal of Business Ethics, 70, 363-373. https://doi.org/10.1007/s10551-006-9115-4

Katmon, N., \& Al Farooque, O. (2017). Exploring the impact of internal corporate governance on the relation between disclosure quality and earnings management in the UK listed companies. Journal of Business Ethics, 142, 345-367. https://doi.org/10.1007/s10551-015-2752-8

Klemperer, P. (1999). Auction theory: A guide to the literature. Journal of Economic Surveys, 13, 227-286. https://doi.org/10.1111/1467-6419.00083

Kothari, S. P., Leone, A. J., \& Wasley, C. E. (2005). Performance matched discretionary accrual measures. Journal of Accounting and Economics, 39, 163-197. https://doi.org/10.1016/j.jacceco.2004.11.002

Krishnaswami, S., \& Subramaniam, V. (1999). Information asymmetry, valuation, and the corporate spin-off decision. Journal of Financial Economics, 53, 73-112. https://doi.org/10.1016/S0304-405X(99)00017-3

Kulkarni, S. P. (2000). Environmental ethics and information asymmetry among organizational stakeholders. Journal of Business Ethics, 27, 215-228. https://doi.org/10.1023/A:1006340624326

Kummer, C., \& Sliskovic, V. (2007). Do virtual data rooms add value to the mergers and acquisitions process? Institute of Mergers, Acquisitions and Alliances (MANDA) (www. manda-Institute.org).

Kurland, N. B. (1995). Ethics, incentives, and conflicts of interest: A practical solution. Journal of Business Ethics, 14, 465-475. https://doi.org/10.1007/BF00872087

Laffont, J. J., \& Martimort, D. (2009). The theory of incentives: The principal-agent model. Princeton. NJ: Princeton University. https://doi.org/10.2307/j.ctv7h0rwr

Lang, M. H., \& Lundholm, R. J. (1996). Corporate disclosure policy and analyst behavior. The Accounting Review, 71, 467-492. https://www.jstor.org/stable/248567

Lin, C. Y., \& Wei, Y. (2006). The role of business ethics in merger and acquisition success: An empirical study. Journal of Business Ethics, 69, 95-109. https://doi.org/10.1007/s10551-006-9070-0

Macias, A. J., \& Moeller, T. (2016). Target signaling with material adverse change clauses in merger agreements. Journal of Empirical Finance, 39, 69-92. https://doi.org/10.1016/j.jempfin.2016.09.002

Masulis, R., \& Simsir, S. (2018). Deal Initiation in Mergers and Acquisitions. Journal of Financial and Quantitative Analysis, 53, 2389-2430. https://doi.org/10.1017/S0022109018000509

Mitchell, M., Pulvino, T., \& Stafford, E. (2004). Price pressure around mergers. Journal of Finance, 59, 31-63. https://doi.org/10.1111/j.1540-6261.2004.00626.x

Mulherin, H., \& Simsir, S. (2015). Measuring deal premiums in takeovers. Financial Management, 44, 1-14. https://doi.org/10.1111/fima.12053

Pástor, L., \& Stambaugh, R. F. (2002). Mutual fund performance and seemingly unrelated assets. Journal of Financial Economics, 63, 315-349. https://doi.org/10.1016/S0304-405X(02)00064-8

Povel, P., \& Singh, R. (2006). Takeover contests with asymmetric bidders. Review of Financial Studies, 19, 1399-1431. https://doi.org/10.1093/rfs/hhj034

Raman, K., Shivakumar, L., \& Tamayo, A. (2013). Target's Std. dev. of discretionary accruals and bidders' takeover decisions. Review of Accounting Studies, 18, 1050-1087. https://doi.org/10.1007/s11142-013-9224-0

Scholes, M. S., Wilson, G. P., \& Wolfson, M. A. (1990). Tax planning, regulatory capital planning, and financial reporting strategy for commercial banks. Review of Financial Studies, 3, 625-650. https://doi.org/10.1093/rfs/3.4.625

Schwert, G. W. (1996). Markup pricing in mergers and acquisitions. Journal of Financial Economics, 41, 153-192. https://doi.org/10.1016/0304-405X(95)00865-C

Schwert, G. W. (2000). Hostility in takeovers: In the eyes of the beholder? Journal of Finance, 55, 2599-2640. https://doi.org/10.1111/0022-1082.00301 
Simsir, S. A. (2008). The information content of deal initiation in mergers and acquisitions. Cornell University Working Paper, http://www.eea-esem.com/files/papers/EEA-ESEM/2008/1457/Initiation_version4_2.pdf

Skaife, H. A., \& Wangerin, D. D. (2013). Target financial reporting quality and m\&a deals that go bust. Contemporary Accounting Research, 30, 719-749. https://doi.org/10.1111/j.1911-3846.2012.01172.x

Statista (2017). Number of merger and acquisition transactions in the United States in 2016, by deal value. Accessed at: https://www.statista.com/statistics/245977/number-of-munda-deals-in-the-united-states/. Access date: August 8, 2017.

Weinstein, G., de Wied, W., \& Kagan. (2020). COVID-19 as a material adverse effect (MAC) under M\&A and Financing agreements. Harvard Law School Forum on Corporate Governance. April 4. Accessed on June 8, 2021

https://corpgov.law.harvard.edu/2020/04/04/covid-19-as-a-material-adverse-effect-mac-under-ma-and-financing -agreements/

White, H. (1980). A heteroskedasticity-consistent covariance matrix estimator and a direct test for heteroscedasticity. Econometrica, 48, 817-830. https://doi.org/10.2307/1912934

Williamson, O. (1985). The economic institutions of capitalism (Free Press, New York).

WilmerHale. (2005). 2005 M\&A Report. Wilmer Cutler Pickering Hale and Dore LLP., Baltimore, MD.

Woodbine, G. F. (2008). Moral choice and the concept of motivational typologies: An extended stakeholder perspective in a western context. Journal of Business Ethics, 79, 29-42. https://doi.org/10.1007/s10551-007-9390-8

Wooldridge, J. M. (2010). Econometric analysis of cross-section and panel data. Second Edition, Cambridge, MA, MIT Press.

Xie, K. (2011). Deal process, asymmetric bidder and target premium. Washington University Working paper, http://papers.ssrn.com/sol3/papers.cfm?abstract_id=1573011

Ye, L. (2008). Indicative bidding and a theory of two-stage auctions. Games and Economic Behavior, 58, 181-207. https://doi.org/10.1016/j.geb.2007.04.005

Zellner A. (1962). An efficient method of estimating seemingly unrelated regression equations and tests of aggregation bias. Journal of the American Statistical Association, 57, 500-509. https://doi.org/10.1080/01621459.1962.10480664

\section{Notes}

Note 1. Research examining the pre-announcement period in the acquisition process is quite new, largely due to the need to extract the merger agreement information from SEC filings. See Boone and Mulherin (2007a, 2007b, 2008, 2009) and Denis and Macias (2013) for more details on this hand-collection process. For an understanding of the legal background of the takeover process, reference Herzel and Shepro (1990). Oler and Smith (2013), Simsir (2008), Xie (2011), and Aktas et al. (2010) all examine the identity of the acquisition initiator.

Note 2. We acknowledge that targets may not perfectly choose their preferred method of sale. In sensitivity tests, we attempt to address this concern using a simultaneous equations framework below. Any bias arising from a difference between the observed and the preferred method of sale for the target would add noise to the results and reduce the likelihood of finding support for our expectations. Acknowledging the potential endogeneity between target initiation and the method of sale, untabulated results from seemingly unrelated regressions suggest that the target initiation variable is one of the strongest predictors of an auction as the method of sale.

Note 3. The number of days of due diligence is based on the information found in the background of the merger. We attempt to identify the first and last day the bidder is conducting a due diligence (or the target is allowing such due diligence). In the cases in which the specific detail is not provided, then the dates are estimated (i.e., the duration between when the confidentiality agreement is signed and when the merger agreement is signed or deal is announced, whatever is mentioned to occur first). We acknowledge that the average days per bidder may not represent the number of days data is available to each individual bidder, particularly in a virtual data room, where all bidders may have access for the entire time period. The use of virtual data rooms is not a required disclosure and not often determinable. Following Skaife and Wangerin (2013), we use the due diligence length as a proxy for due diligence quality. Results are qualitatively similar if we use the number of bidders who signed a confidentiality agreement. 
Note 4. We exclude Asymmetric uncertainty in the comprehensive Model 8 because of its high correlation with Std. dev. of discretionary accruals from its construction (see variable definitions in Appendix A).

Note 5. For instance, in model (7) the Hosmer Lemeshow (2000) test is 0.625 (a probability of chi^2 $>0.10$ means a well-fitted model) and the area under the receiver-operator characteristic (ROC) curve (Sensitivity vs. 1-Specificity graph) test is 0.641 (test values between 0.6 and 0.9 mean a well-fitted model). Similar specification and goodness of fit tests also confirm the rest of the logistic models presented in the paper.

Note 6. In untabulated tests, we consider the possibility that the decisions to sell the firm and the choice of method of sale are jointly determined. We estimate various systems of equations (i.e., seemingly unrelated regressions, bi-probit and treatment effect regressions) and find that the adverse selection proxies we consider are strongly related to the decision to sell the firm and that target initiation is positively related with the likelihood of using an auction as the method of sale.

Note 7. All return windows are relative to day 0 , where day 0 is the initial announcement date. To calculate the LT abnormal returns we use the Fama-French 3 factor model, in which the CRSP value-weighted index proxies for the market. Our results are qualitatively similar when we use alternative announcement LT return windows (e.g., -30, +126 or $-30,+63$ ). $50.3 \%$ of the acquisitions (331 out of the 658 transactions) are completed before day +126 . Our results for the bidder's LT returns are robust to estimating a constant $[-63,+126]$ window, regardless of the date of the completion or termination, if such date is earlier than 126 days after the announcement date.

Note 8 . The arbitrage spreads - the difference between the price offered to target shareholders and the current market price of the target's shares - disappear as the acquisition reaches its completion (see, e.g., Brown \& Raymond, 1986; Mitchell, Pulvino, \& Stafford, 2004; and Denis \& Macias, 2012).

Note 9. Some examples of research that use SUR to exploit the additional information contained in the contemporaneous cross-equation error correlation are Jaffee, Keim and Westerfield (1989), Scholes, Wilson and Wolfson (1990), and Pástor and Stambaugh (2002). 


\section{Appendix A: Variable definitions}

\section{Variable \\ Main variables of interest}

Target initiation

Auction

\section{Target information asymmetry}

Std. dev. of net income

Discretionary accruals

Std. dev. of discretionary accruals

Asymmetric uncertainty

Avg. institutional ownership

Number of analysts

\section{Target financial distress}

Altman's Z-score

Interest coverage

Liquidity ratio

LT debt / EBITDA

BHAR prior year

\section{Target firm Characteristics}

Mkt. value assets

\section{Description}

Main source: SEC Proxy files and LivEdgar.

Binary variable $=1$ if target's management initiated the deal.

Binary variable $=1$ if there are multiple bidder during the pre-announcement takeover process. The alternative value is zero for single-bidder acquisitions, which we label as negotiations.

Main source: Compustat and IBES.

Standard deviation of net income.

The residual from the following model (averaged over years t-1 \& $\mathrm{t}-2$ ): $\mathrm{CAi}+$ CAi,t-1 $=\alpha+\beta(\Delta$ Salesi $-\Delta$ ARi $+\Delta$ Salesi,t-1 $-\Delta$ ARi, t-1 $)+\varepsilon i$ minus the average residual of a portfolio of firms matched on two-digit SIC codes and ROAt-1, where CA is current accrual: data items [ $\Delta(4-1)-\Delta(5-34)] / 6 t-1$; Sales (data12/data6t-1); AR is accounts receivable (data $2 /$ data6t-1).

As measured by the Dechow and Dichev (2002) and

McNichols (2002) methods. We first run a regression of the firm's accruals on cash from operations, lagged cash from operations, lead cash from operations, change in revenue and gross plant, property and equipment. Then we estimate Std. dev. of discretionary accruals as the standard deviation of the firm's residuals of such firm-year regressions over years t-5 to t-1 where a higher value indicates lower Std. dev. of discretionary accruals. (For more details, see Raman et al., 2013).

As measured by Raman et al. (2013): the fitted values from the regressions of target Std. dev. of discretionary accruals on bid-ask spread.

Average stock ownership during the prior year of the acquisition.

Number of analysts following target firm. Source: IBES.

Main source: Compustat and CRSP.

Following Altman (1968): altmanz $=1.2 *[($ act-lct $) / a t]+1.4 *[$ re/at $]+3.3 *[($ pi + xint $) / a t]$ $+0.6 *[\mathrm{csho} *$ prcc_f $/ \mathrm{lt}]+0.999 *[$ sale $/$ at $]$

EBIT divided by interest expense.

Current assets divided by total assets.

Book value of long-term debt divided by EBITDA.

Buy-and-Hold abnormal returns (including dividends) 1 year before the acquisition announcement date. The gross returns are adjusted by the return of equally weighted average return of the market the returns are The buy-and-hold abnormal returns is then defined as the target firm's buy-and-hold returns minus the median of the buy-and-hold returns to the control group.

Main source: Compustat and CRSP.

Book value of assets (data6) - book value of equity (data60) + common shares outstanding (data25) *FY closing price (data199). 


\section{ROA (EBITDA/assets)}

Tobin's Q

R\&D-to-sales

LT leverage

Regulated industry

Technology industry

Strong anti-takeover state

Bidder firm characteristics

Bidder mkt. value assets

Bidder ROA (EBITD/assets)

Bidder Tobin's Q

Bidder R\&D-to-sales

\section{Competition level}

M\&A liquidity index

Buyout activity

Economic recession

Internet bubble deflation
Ratio between operating income before depreciation (data13)/total assets (data6). Tobin's Q is calculated as follows: [assets (data6) + common shares outstanding (data25)* FY closing price (data199) - book value of equity (data60) - deferred taxes (data74)/assets (data6)]

Calculated as follows: [assets (data6) + common shares outstanding (data25)* FY closing price (data199) - book value of equity (data60) - deferred taxes (data74)/assets (data6)]

Research and development expenditures divided by sales.

Book value of long-term debt / market value of assets.

Binary variable $=1$ if the target's main industry is in the following industries (using Fama-French industry classifications): Defense, Petroleum and Natural Gas, Utilities, Communication, Banking, Insurance or Trading.

Binary variable $=1$ if the target's main industry is in the following industries (using Fama-French industry classifications): Medical Equipment, Pharmaceutical Products, Machinery, Defense, Computers, Chips-Electronic Equipment, and Measuring and Control Equipment.

Binary variable $=1$ if the target's state of incorporation is a strong antitakeover state shown by Bebchuk and Ferrell (2002) to have all five of the antitakeover statutes: Idaho, Indiana, Maryland, Nevada, Ohio, Pennsylvania, South Dakota, Tennessee, and Wisconsin.

Main source: Compustat and CRSP.

Book value of assets (data6) - book value of equity (data60) + common shares outstanding (data25) *FY closing price (data199)

Ratio between operating income before depreciation (data13)/total assets (data6). Tobin's Q is calculated as follows: [assets (data6) + common shares outstanding (data25)* FY closing price (data199) - book value of equity (data60) - deferred taxes (data74)/assets (data6)]

calculated as follows: [assets (data6) + common shares outstanding (data25)* FY closing price (data199) - book value of equity (data60) - deferred taxes (data74)/assets (data6)]

Research and development expenditures divided by sales.

Main source: SDC and NBER

The ratio of the value of corporate control transactions during the year relative to the aggregate book value of assets of firms in each two-digit SIC code.

The aggregate investment by US private buyout funds by year divided by the aggregate NYSE, Amex and Nasdaq market value.

A binary variable coded 1 if a transaction takes place during a recessionary period (March 2001-November 2001 per NBER).

A binary variable coded 1 if year is 2000 or 2001 based on when the internet bubble deflated (i.e., the number of deals started to decline in comparison to the prior 2 years). 


\section{Deal characteristics}

Challenged deal

Tender

Diversified deal

Only cash payment

Hostile-Unsolicited
Main source: SDC.

Binary variable $=1$ if another bidder makes an offer for the target after the initial public announcement according to SDC.

Binary variable $=1$ if a takeover bid takes the form of a public invitation to shareholders to sell their stock, with or without prior contact with the target according to SDC.

Binary variable $=1$ if the primary industry of the target is different as that of the bidder, based on the Fama French 48 industry classification.

Binary variable $=1$ if the offered price is made $100 \%$ in cash.

Binary variable $=1$ if the acquisition started as a hostile or unsolicited deal according to SDC.

\section{Copyrights}

Copyright for this article is retained by the author(s), with first publication rights granted to the journal.

This is an open-access article distributed under the terms and conditions of the Creative Commons Attribution license (http://creativecommons.org/licenses/by/4.0/). 